\title{
RELASI KUASA DALAM NOVEL ANAK RANTAU KARYA AHMAD FUADI : KAJIAN TEORI MICHEL FOUCAULT
}

\author{
Ratna Ayuningtyas \\ SMP Yayasan Pendidikan dan Sosial Ma'arif 1 Taman Sidoarjo \\ Jl. Raya Ngelom no 86 Kec Taman, Kab Sidoarjo, Indonesia \\ Pos-el: aningcwilly59@gmail.com
}

\begin{abstract}
This study attempts to describe relation power and representation of relation power in a novel the Anak Rantau by ahmad fuadi, also describe media power. Dispersal device types of data used in this research is qualitative data. The subject of this research is a novel the Anak Rantau by ahmad fuadi. This study focused on problems associated with my counterparts power. The data obtained by read and noted Technique. Data analyzed by qualitative description technique. The validity of the data obtained through validity and reabilitas. The result showed that: (1) relation power in a novel Anak Rantau is for ever thinking and upper body. Types of relationships power over the thought of objectification, manipulation, domination stigmatization of, and control.Types of relationships power over the body of the form of objektive, manipulation and control, (2) there is dispersal device media, religion of power cultural and educational institutions.
\end{abstract}

Keywords: relation power, power

\begin{abstract}
Abstrak
Penelitian ini bertujuan untuk mendeskripsikan bentuk-bentuk relasi kuasa dan representasi relasi kuasa dalam novel Anak Rantau karya Ahmad Fuadi. Selain itu, juga memapaparkan media penyebar kuasa. Jenis data yang digunakan dalam penelitian ini adalah data kualitatif. Subjek penelitian ini adalah novel Anak Rantau karya Ahmad Fuadi. Penelitian ini difokuskan pada permasalahan yang berkaitan dengan relasi kuasa. Data diperoleh dengan teknik membaca dan mencatat. Data dianalisis dengan teknik dekspripsi kualitatif. Keabsahan data diperoleh melalui validitas dan reabilitas. Hasil penelitian menunjukkan bahwa: (1) relasi kuasa dalam novel Anak Rantau adalah atas pemikiran dan atas tubuh. Bentuk relasi kuasa atas pemikiran berupa obyektifikasi, manipulasi, dominasi, stigmatisasi, dan kontrol. Bentuk relasi kuasa atas tubuh berupa bentuk obyektifikasi, manipulasi, dan kontrol, (2) terdapat penyebar media kuasa yaitu Agama, Budaya dan Lembaga Pendidikan
\end{abstract}


Kata kunci: Relasi Kuasa, Kekuasaan

\section{PENDAHULUAN}

Karya sastra merupakan ciptaan untuk tujuan estetika. Menurut Plato dalam (Faruk, 2012: 47) dunia dalam karya sastra merupakan tiruan terhadap dunia kenyataan yang sebenarnya juga dunia ide. Dunia dalam karya sastra membentuk diri sebagai sebuah dunia sosial yang merupakan tiruan terhadap dunia sosial yang ada dalam kenyataan. Karya sastra bisa saja dianggap sebagai kekuatan fiktif dan imajinatif untuk dapat secara langsung menangkap bangunan sosial secara langsung.

Karya sastra juga mampu menggambarkan objek-objek dan gerak-gerik yang terdapat dalam dunia pengalaman. Satu di antara objek dan gerak-gerik yang ada dalam dunia pengalaman langsung adalah soal kekuasaan. Terdapat relasi kekuasaan yang mendefinisikan sifat kompleks dari hubungan masyarakat dengan kelompok- kelompok pemimpin masyarakat. Artinya hubungan tersebut tidak hanya soal politis dalam pengertian sempit, tetapi juga mengenai persoalan gagasan dan kesadaran (Faruk, 2012: 144).

Persoalan dalam gagasan tersebut dibuat sebagai legitimasi kekuasaan. Menurut Foucault (2007:59) kekuasaan dalam realitas direpresentasikan dengan dua cara. Pertama adalah dengan kekerasan dan tindakan represif. Kedua, kekuasaan dijalankan dengan terselubung. Kekuasaan yang direpresentasikan dengan kekerasan dan tindakan represif misalnya membuat orang patuh dengan ancaman pistol dan ancaman fisik lainnya. Sedangkan kekuasaan yang direprsentasikan dengan terselubung misalnya lewat ilmu pengetahuan dan lembaga-lembaga pendidikan. Pembicaraan mengenai kekuasaan merupakan satu hal menarik yang tidak pernah selesai dibahas. Hal ini telah dimulai sejak zaman Yunani kuno dan terus berlangsung sampai zaman ini. Para filsuf klasik pada umumnya mengaitkan kekuasaan dengan kebaikan, kebajikan, keadilan dan kebebasan. Para pemikir religius menghubungkan kekuasan itu dengan Tuhan. Kekuasaan politik hanya sebagai alat untuk mengabdi tujuan negara yang dianggap agung dan mulia, yaitu kebaikan, kebajikan, keadilan, kebebasan yang berlandaskan kehendak Tuhan dan untuk kemuliaan Tuhan.

Berkaitan dengan karya sastra sebagai bayangan atau pantulan keadaan masyarakat, 
menurut Watt dalam (Endraswara, 2011: 81), bahwa fungsi sosial sastra adalah; (a) sebagai pembaharu atau perombak, (b) sebagai penghibur belaka, dan (c) sebagai pengajaran sesuatu dengan jalan menghibur. Masyarakat sebagai sasaran sekaligus sebagai penikmat karya sastra akan menilai seberapa jauh fungsi suatu karya sastra yang berkaitan dengan kehidupan masyarakat. Dengan demikian, karya sastra tertentu memiliki fungsi sosial politik, sosial spiritual, sosial budaya, atau yang lainnya, tergantung kesan dari masyarakat pembaca.

Karya sastra juga disebut sebagai cermin kehidupan masyarakat, sesuai pendapat Abrams dalam (Endraswara, 2011: 89), bahwa sebuah novel tidak hanya mencerminkan realitas melainkan lebih dari itu. Novel / karya sastra memberikan sebuah refleksi realitas yang lebih besar, lebih lengkap, lebih hidup, dan lebih dinamika yang mungkin melampaui pemahaman umum. Sebuah karya sastra tidak hanya mencerminkan fenomena individual secara tertutup melainkan lebih merupakan sebuah proses yang hidup. Karya sastra adalah adalah karya seni yang mediumnya sudah bersifat tanda yang mempunyai arti yaitu bahasa (Pradopo, 2009: 47). Lewat medium bahasa karya sastra berbicara mengenai manusia dan kemanusiaan, sedangkan manusia tidak terlepas dari keberadaannya sebagai makhluk sosial dan budaya.

Novel Anak Rantau karya Fuadi (2018) mengangkat tema anak rantau yang justru merantau di kampung halaman ayahnya. Ia menuliskan setiap adegan dan suasana dengan detail, membuat pembaca seakan-akan berada pada cerita tersebut. Banyak adat istiadat yang dihadirkan dalam cerita ini, membuat para pembaca sedikit tahu tentang adat Minang. Bukan hanya adat, melainkan juga pepatah khas orang Minang dahulu. Antara bab satu dengan bab yang lainnya terdapat kesinambungan. Di awal cerita, ditampilkan cuplikan akhir cerita yang membuat penasaran. Terdapat peta di sampul belakang, membuat pembaca dapat lebih paham mengenai lokasi Kampung Tanjung Durian.

Berdasarkan latar belakang di depan, penelitian ini mengungkapkan relasi kekuasaan yang hadir di tengah masyarakat, baik melalui adat, lembaga pemerintah, sekolah, hingga ilmu pengetahuan. Untuk membongkarnya akan digunakan analisis kekuasaan dari perspektif Michael Foucault, seorang sosiolog sekaligus filsuf asal Prancis. Dengan kajian relasi kuasa, diharapkan pembaca bisa memahami bahwa dalam masyarakat, negara atau pihak penguasa tidak selalu merepresentasikan kekuasaan melalui cara yang represif, 
melainkan bisa juga dengan cara yang lembut. Selain itu, penelitian ini juga akan memberikan gambaran bahwa kekuasaan yang dijalankan dengan terselubung dalam ilmu pengetahuan akan bersifat kekal dan mampu terekam oleh sebuah karya fiksi.

Sosiologi sastra, yang memahami fenomena sastra dalam hubungannya dengan aspek sosial, merupakan pendekatan atau cara membaca dan memahami sastra yang bersifat interdisipliner. Oleh karena itu, sebelum menjelaskan hakikat sosiologi sastra, seorang ilmuwan sastra seperti Swingewood dalam The Sociology of Literature (2013) terlebih dulu menjelaskan batasan sosiologi sebagai sebuah ilmu, batasan sastra, baru kemudian menguraikan perbedaan dan persamaan antara sosiologi dengan sastra. Swingewood (2013) menguraikan bahwa sosiologi merupakan studi yang ilmiah dan objektif mengenai manusia dalam masyarakat, studi me-ngenai lembaga-lembaga dan proses sosial. Sosiologi berusaha menjawab pertanyaan mengenai bagaimana masyarakat dimungkinkan, bagaimana cara kerja-nya, dan mengapa masyarakat itu bertahan hidup.

Baik sosiologi maupun sastra memiliki objek kajian yang sama, yaitu manusia dalam masyarakat, memahami hubungan-hubungan antarmanusia dan proses yang timbul dari hubungan-hubungan terse-but di dalam masyarakat. Bedanya, kalau sosiologi melakukan telaah objektif dan ilmiah tentang manusia dan masyarakat, telaah tentang lembaga dan proses sosial, mencari tahu bagaimana masyarakat dimungkinkan, bagaimana ia berlangsung, dan bagaimana ia tetap ada; maka sastra menyusup, me-nembus permukaan kehidupan sosial dan menun-jukkan cara-cara manusia menghayati masyarakat dengan perasaannya, melakukan telaah secara subjektif dan personal (Damono,2005).

Swingewood memandang adanya dua corak penyelidikan sosiologi yang mengunakan data sastra. Yang pertama, penyelidikan yang bermula dari lingkungan sosial untuk masuk kepada hubung-an sastra dengan faktor di luar sastra yang terbayang dalam karya sastra. Oleh Swingewood, cara seperti ini disebut sociology of literature (sosiologi sastra). Penyelidikan ini melihat faktor-faktor sosial yang menghasilkan karya sastra pada masa dan masya-rakat tertentu. Kedua, penyelidikan yang menghubungkan struktur karya sastra kepada genre dan masyarakat tertentu. Cara kedua ini dinamakan sosiologi sastra.

Dalam paradigma studi sastra, sosiologi sastra, terutama sosiologi karya sastra, dianggap sebagai perkembangan dari 
pendekatan mimetik, yang dikemukakan Plato, yang memahami karya sastra dalam hubungannya dengan realitas dan aspek sosial kemasyarakatan. Pandangan tersebut dilatarbelakangi oleh fakta bahwa keberadaan karya sastra tidak dapat terlepas dari realitas sosial yang terjadi dalam masyarakat. Seperti yang pernah dikemukakan oleh Damono (2005), salah seorang ilmuwan yang mengembangkan pendekatan sosiologi sastra di Indonesia, bahwa karya sastra tidak jatuh begitu saja dari langit, tetapi selalu ada hubungan antara sastrawan, sastra, dan masyarakat.

Oleh karena itu, pemahaman terhadap karya sastra pun harus selalu menempatkannya dalam bingkai yang tak terpisahkan dengan berbagai variabel tersebut: pengarang sebagai anggota masyarakat, kondisi sosial budaya, politik, ekonomi yang ikut berperan dalam melahirkan karya sastra, serta pembaca yang akan membaca, menikmati, serta memanfaatkan karya sastra tersebut.

Sulistya dkk., (2011: 135) mendefinisikan relasi kuasa sebagai sesuatu yang membuat orang patuh.Relasi kuasa merupakan konsep hubungan kekuasaan yaitu praktik-praktik kekuasaan dari subjek pada obyek melalui berbagai media dan rupa Kekuasaan yang dimaksudkan tidak didapat dari cara- cara yang represif, melainkan secara manipulatif dan hegemoni.

Kekuasaan, bagi Foucault (2013) adalah soal praktik-praktik konkrit yang lantas menciptakan realitas dan pola-pola perilaku, memproduksi wilayah objek- objek pengetahuan dan ritual-ritual kebenaran yang khas.Praktikpraktik itu menciptakan normanorma yang lalu direproduksi dan dilegitimasi melalui para guru, pekerja sosial, dokter, hakim, polisi dan administrator, misalnya. Kekuasaan mewujudkan diri dalam pengetahuan, tetapi pengetahuan pun lantas melahirkan kekuasaan.

Lebih lanjut Sulistya dkk., (2011: 135) menyatakan bahwa kekuasaan disalurkan melalui hubungan sosial, memproduksi bentuk perilaku seperti baik dan buruk, dan menciptakan prosedur dan aturan yang mampu menundukan masyarakat. Ada lima cara kekuasaan itu beroperasi berupa : (1) Kekuasaan tidak diambil, diperoleh, atau dibagikan. Kekuasaan berjalan dari berbagai titik, dalam hubungan yang tidak setara dan selalu bergerak. (2) Kekuasaan bersifat cair. Maksudnya kekuasaan adalah efek langsung dari pembagian, pembedaan,ketidaksetaraan,danket idakseimbangan. (3) Hubungan kekuasaan tidak berada dalam posisi suprastruktur. Kekuasaan datang dari bawah, artinya tidak ada oposisi biner antara yang mendominasi dan yang dominan. 
Hubungan semacam itu terbentuk dalam aparat produksi seperti dalam keluarga, kelompok, maupun institusi. (4) Hubungan kekuasaan bersifat intensional. Tidak ada kekuasaan tanpa serangkaian sasaran. Rasionalitas kekuasaan adalah taktik yang terselubung pada tingkat teratas. (5) Kekuasaan selalu mendapatkan tandingan kuasa lainnya dimanapun berada. Kekuasaan selalu melahirkan anti kekuasaan. Anti kekuasaan tersebut sebenarnya adalah untuk mengejawantahkan kekuasaan lainnya sebagai tandingan.

Sasaran kekuasaan menurut Jones, (2012: 175) bisa siapa saja. Baik individu atau kelompok. Relasi kuasa beroperasi pada pemikiran (ideologi) hingga tubuh, yang akhirnya mempengaruhi perilaku.

\section{METODE PENELITIAN}

Siswantoro

(2010:47)

mengungkapkan bahwa pendekatan merupakan alat untuk menangkap realita atau fenomena sebelum dilakukan kegiatan analisis. Pendekatan hendaknya digunakan oleh seorang analisis, kerangka konseptual, kerangka pemikiran, paradigma dalam usaha memahami realita sebelum melakukan analisis interpretatif terhadap sebuah puisi, novel, drama, atau lainnya.

Penelitian ini menggunakan pendekatan sosiologi sastra. Sosiologi merupakan ilmu sosial yang objeknya adalah masyarakat. Dalam dunia masyarakat terdapat hubungan sosial yang isinya adalah sebuah karya sastra. Masyarakat menjadi objek utama para pengarang dalam membuat karya sastra, khususnya karya sastra tentang sosial. Fenomena atau hal-hal yang terjadi dalam masyarakat menjadi bahan untuk para pengarang dalam menciptakan karya sastra. Pendekatan sosiologi sastra berfokus relasi kuasa yang ada dalam masyarakat berdasarkan teori Michel Faucoult.

Dalam pendekatan sosiologi sastra berfokus pada relasi kuasa yang terdapat dalam novel Anak Rantau karya Ahmad Fuadi. Menurut Foucault, kekuasaan adalah satu dimensi dari relasi. Di mana ada relasi, di sana ada kekuasaan. Kuasa itu ada di manamana dan muncul dari relasi-relasi antara berbagai kekuatan, terjadi secara mutlak dan tidak tergantung dari kesadaran manusia. Kekuasaan hanyalah sebuah strategi. Strategi ini berlangsung di mana-mana dan di sana terdapat sistem, aturan, susunan dan regulasi. Kekuasaan ini tidak datang dari luar, melainkan kekuasaan menentukan susunan, aturan dan hubungan-hubungan dari dalam dan memungkinkan semuanya terjadi. 


\section{HASIL DAN PEMBAHASAN Relasi Kuasa}

1. Relasi Kuasa atas Pemikiran

Banyak bentuk relasi kuasa atas pemikiran dalam novel Anak Rantau. Bentuk relasi tersebut adalah manipulasi, stigmatisasi, dominasi, dan pengontrolan atas pemikiran. Disederhanakan oleh Sugiharto (2012) bentuk relasi Michael Foucault ini merupakan landasan berpikir atau kognitif masyarakat pada suatu zaman. Artinya, masyarakat pada zaman tertentu diatur, dikontrol, didominasi, distigmatisasi oleh banyak kekuasaan yang nantinya akan membuat landasan berpikir masyarakat mengikuti pembuat kuasa dalam waktu dan di tempat tertentu. Berikut adalah bentuk relasi kuasa yang ditemukan dalam novel Anak Rantau karya Ahmad Fuadi.

\section{Manipulasi Pemikiran}

Manipulasi adalah sebuah proses rekayasa dengan melakukan penambahan, penyembunyian, penghilangan atau pengkaburan terhadap bagian atau keseluruhan sebuah realitas, kenyataan, faktafakta ataupun sejarah yang dilakukan berdasarkan sistim perancangan sebuah tata sistem nilai, selain itu manipulasi merupakan bagian penting dari tindakan penanaman gagasan, sikap, sistem berpikir, perilaku dan kepercayaan tertentu. Hal yang penting dari manipulasi pemikiran adalah mempelajari cara menguasai emosi dan membuat orang lain percaya dengan perasaan yang tidak sebenarnya dengan cara menggunakan berbagai teknik emosional agar dapat meyakinkan orang untuk mengembangkan kekuatan persuasi. Dalam novel Anak Rantau karya Ahmad Fuadi terdapat manipulasi pemikiran yang tertulis dalam kutipan berikut

[1] Sosok Pendeka Luko semakin gaib karena tidak pernah tampak di muka umum. Para orang tua di kampung memanfaatkan sosok pendeka ini untuk menakut-nakuti anak mereka. Kalau malas mandi, malas makan, tidak patuh sama orang tua, mereka ditakuttakuti bahwa nanti malam Pandeka Luko akan mengetuk rumah mereka, akan dibuat buncit dan tidak bisa melihat. Biasanya anak-anak ini akan pucat lalu mengubah kelakuannya., berharap tidak diusik pandeka. Dari waktu ke waktu, kalau ada kejadian misterius di kampung, Pandeka Lukolah yang dikambinghitamkan. Kalau ada yang bertingkah aneh dan jahat, maka warga menegurnya dengan kata-kata :"janganlah kau seperti Pandeka Luko." (Fuadi, 2018:216-217) 
Dari data [1] diceritakan bahwa ada sesosok Pandeka Luko yang dimanfaatkan masyarakat agar nama tersebut menjadi sorotan publik bahwa dia adalah seorang yang misterius. Masyarakat menyebarkan informasi tersebut tanpa ada pembuktian yang kuat. Akan tetapi, informasi itu dibuat untuk menakut-nakuti anak-anak, sehingga mereka percaya dan takut dengan cerita tersebut. Para orangtua memanipulasi pemikiran anak-anak agar patuh kepada mereka. Adanya informasi itu akibat cerita yang disebarkan dari mulut ke mulut. Dan sering terjadi bahwa wacana tersebut dilebihlebihkan dan jauh dari kenyataan yang ada, hal itu terdapat dalam kutipan berikut :

[2] Attar tambahkan pula kalau ada yang bilang tangan Pandeka Luko tinggal satu karena tangan kirinya diamputasi setelah membusuk kena beyonet Belanda. Diujung tangannya yang kudung kini terpasang selongsong besi berkait. Lalu dengan tangan cakar itu dia menangkap mangsanya seperti kelelawar, tokek, dan labi-labi yang dimakan mentah demi kelangsungan ilmu gaibnya. (Fuadi, 2018:218)

Dari data [2] diceritakan bahwa ilmu gaib itu ada. Mereka percaya tentang tumbal adalah mangsa untuk kelangsungan ilmu gaib. Perkembangan masyarakat Indonesia sejak zaman dulu, selalu diwarnai dengan nuansa-nuansa magis, kepercayaan pada hal-hal irasional, dan selanjutnya berbaur dengan nilai-nilai religius. Pada titik tertentu bahkan hal-hal yang mistis tersebut mampu melampaui realitas sebenarnya. Hal ini menjadi dasar terbentuknya pandanganpandangan awal mengenai kepercayaan bangsa Indonesia terhadap hal-hal yang berbau magis ataupun hal-hal gaib. Kepercayaan itu bahkan sudah ditanamkan sejak kecil melalui cerita-cerita tradisional. Memang kebanyakan kepercayaan seperti itu masih kental di daerah-daerah yang lebih tradisional.Kemudian selain ilmu gaib, mereka juga percaya dengan mitos. Hal ini terdapat dalam kutipan berikut :

[3] Sebagai anak yang bangga dengan kampungnya, Zen hafal semua hikayat dan legenda Tanjung Durian, diapun memulai kisahnya dengan menggebu-gebu. Anak-anak itu tahu dari mulut ke mulut kalau surau tua mereka ini sudah lama punya jemaah tambahan beberapa keluarga jin Islam. Cerita ini tidak ada buktinya sampai ada cerita tambahan beberapa tahun lalu. (Fuadi, 
2018:177)

Dalam data [3] terlihat jelas bahwa orang-orang masih percaya dengan adanya mitos tersebut. Mitos adalah sebuah imajinasi dari manusia yang berusaha untuk menerangkan gejala alam yang ada pada saat itu yang dikaitkan dengan kepercayaan akan adanya kekuatan ghaib. Namun, disebabkan oleh keterbatasan manusia dalam menjelaskan hal tersebut sehingga cenderung diidentikkan dengan seorang dewa/dewi, tokoh misteri serta sesuatu yang berbau mistis. Sehingga pengetahuan yang diperoleh bersifat subyektif. Hal ini terdapat pada kutipan berikut :

[4] Cerita ini kemudian bertambah-tambah, setiap pindah ke kuping dan mulut. Belakangan ini ada pula orang yang mengaku kerap melihat bayangan putih mondarmandir di bawah kubah dengan bentuk khas. Dipuncak kepala bayangan itu, ada ikat kepala putih yang menjulang. (Fuadi, 2018:178)

[5] Jangan main-main sama jin, bisa kesurupan dan diculik ke alam gaib. (Fuadi, 2018:181)

[6] Sampai Pak Sinayan
menyeletuk
membenarkan

kacamatanya, “jangan-
jangan ini pekerjaan gaib?
Para peronda ditenung,
dipukau oleh kekuatan
gaib sehingga tidak melihat
para pencuri beraksi".
(Fuadi, 2018:204)

Dari kutipan data [4], [5], [6] bentuk relasi pemikiran yang bersifat manipulasi. Wacana datang dari mulut ke mulut ini tentang adanya makhluk gaib agar masyarakat mempercayainya sehingga setiap ada kejadian yang aneh, otomatis orang-orang sudah mengubah pola pikirnya bahwa hal tersebut terjadi karena adanya makhluk gaib. Dari semua data tersebut terjadilah relasi kuasa atas masyarakat yang dewasa dengan anak-anak. Masyarakat yang sudah dewasa itu memberikan wacana manipulasi kepada anak-anak agar mereka percaya dengan hal-hal gaib, sehingga pola pikir anak-anak dapat berubah akan kepercayaan tersebut.

\section{Stigmatisasi}

Dalam novel Anak Rantau, terdapat asupan yang dimasukan ke dalam pikiran terus menerus. Bentuk pengasupan yang dimasukan dalam pikiran adalah stigmatisasi. Contohnya mengenai penggolongan sikap dan perilaku manusia yang tidak sesuai dengan ajaran agama. Stigmatisasi ini diasupi terus menerus hingga 
mengendap dalam pemikiran. Dalam novel ini, data yang ditemukan adalah sebagai berikut.

[8] : Dulu ketika mencari-cari ilham untuk nama anak keduanya, dia mendengar sebuah lagu bahasa Inggris dengan irama yang menenangkan : 'Don't worry, be happy". Dia sangat suka dan jadilah itu nama anaknya. Di akta kelahiran dia dituliskan dengan mantap : Donwori Bihepi. Panggilannya Hepi. Nama adalah doa. (Fuadi,2018: 57)

Dalam kutipan data [8] dituliskan bahwa tokoh Martiaz yaitu ayah Hepi menstigmatisasi pemikiran bahwa nama adalah doa. Dalam pemberian nama, para orang tua takkan lepas dari harapan-harapan kebanggaan tersendiri terhadap nama yang diberikan. Nama merupakan harapan agar anak sepadan atau sederajat dengan manusia pada umumnya. Karena salah satu syarat diakuinya derajat manusia dengan yang lainnya karena manusia memiliki sebuah nama. Besarnya harapan orang tua melalui nama yang diberikan kepada anaknya dipengaruhi oleh besarnya kecintaan orang tua kepada anak. Orang tua berharap agar anak kelak bisa tumbuh dewasa sesuai dengan kandungan makna dalam nama tersebut. Sebagai orang tua muslim yang taat kepada Allah tentu akan meletakkan harapan yang benar, yakni harapan agar anaknya kelak tumbuh dewasa menjadi insan saleh. Karena dengan kesalehan yang dimilikinya niscaya ia akan menjadi insan yang tampan, lebih cantik, lebih kaya dan lebih tinggi pangkatnya di mata Allah SWT serta akan terwujud kelak semua harapan dalam kehidupan serta abadi. Selain itu dalam pandangan agama, nama juga mengandung unsur doa. Bagi telinga kedua orang tua nama anak seperti suara musik yang sangat merdu.Dengan sering diucapkan oleh banyak orang.maka doa yang terkandung dalam nama itu diharapkan akan mensupport si empunya anak untuk berperilaku sebagaimana kandungan makna dari nama tersebut. Hal ini membuktikan bahwa dalam pelabelan predikat atau stigma mampu mengubah cara pandang dan landasan berpikir individu.

Selain itu, stigmatisasi juga terjadi ketika adanya pemasukan wacana ilmu pengetahuan ke dalam pikiran secara terusmenerus. Penyebaran wacana ilmu pengetahuan di sekolah untuk menentukan mana yang baik dan yang tidak dengan bentuk stigmatisasi ditunjukan oleh data berikut.

[9] Karena itu dia tidak naik kelas. Tapi maaf ya pak, melihat perilakunya yang 
tidak serius di sekolah, kami sarankan Hepi pindah ke SMP lain saja. (Fuadi,2018:9)

\section{Dalam kutipan data [9]} diceritakan bahwa di sekolah tokoh Hepi tidak bisa naik kelas karena dianggap siswa yang kurang serius dalam belajar. Kategorisasi atau penentuan sifat buruk tersebut direpresentasikan melalui raport kosong yang diberikan guru kepada orangtuanya. Segala bentuk yang diberikan pihak sekolah semata-mata peraturan yang telah ditetapkan. Apabila siswa tidak mematuhi peraturannya, maka harus siap menerima resikonya. Dengan peraturan tersebut, Hepi tidak bisa naik kelas. Ayah Hepi memutuskan untuk memindahkan Hepi dari sekolahnya. Dari data [9] terjadi relasi kuasa antara guru dengan orangtua ketika penerimaan raport. Dalam cerita tersebut dijelaskan bahwa guru berkuasa atas perilaku anak disekolah, sehingga guru mempunyai peraturan tentang kedisiplinan di sekolah, apabila mereka sudah memberi peraturan kemudian dilanggar, maka guru akan memberitahukan konsekuensinya kepada orang tua murid tersebut.

\section{Dominasi}

Dalam Novel Anak Rantau asupan pikiran juga dipengaruhi oleh dominasi. Masyarakat pada umumnya berpikir bahwa dengan mempunyai banyak uang dapat melakukan apa saja yang diinginkannya. Asupan itu dimasukkan terus menerus sehingga pikiran manusia terpengaruhi oleh kekuasaan materi duniawi. Hal ini terdapat dalam kutipan berikut :

[10] "Memang kau masih berotak kecil, belum bisa diajak bicara seperti orang dewasa. Kalau bisa berhenti begitu saja alangkah enaknya . Tapi, aku masih perlu uang untuk hidup dan memberi makan teman-teman, bantu anak yatim, dan berinfak untuk surau dan masjid. Harus ada orang yang menghasilkan uang banyak untuk semua ini. jadi gini, aku ini orang hitam tapi ingin menjadi putih. Cuma saat ini baru bisa abu-abu. Ini mungkin nasib perjalanan hidupku." Kata Lenon (Fuadi, 2018:324)

Dalam data [10] diceritakan bahwa Lenon mempunyai pemikiran bahwa uang adalah segalanya. Dengan uang dia dapat membeli apa saja bahkan dia bisa membantu orang lain, tanpa harus memikirkan dengan cara apa dia mendapatkan uang tersebut. Dia telah di dominasi oleh harta, sehingga asupan itu telah 
tertanam di dalam pikirannya.

\section{Pengontrolan Pikiran}

Pengontrolan pikiran bukanlah merupakan penekanan ataupun penindasan pikiran, sebab pikiran yang tertekan ataupun tertindas akan menimbulkan dampak yang tidak sehat. Pengontrolan pikiran tidak sama dengan penghambatan perkembangan pikiran, justru perkembangan pikiran tidak boleh sama sekali untuk dihalang-halangi. Jadi, pengontrolan pikiran merupakan pengarahan pikiran kepada hal-hal yang positif. Pikiran diharapkan berkembang pada alur yang positif. Dalam novel Anak Rantau terdapat dalam kutipan :

[11] Di depan lima anak termasuk Hepi, Zen, dan Attar yang bersila mengelilingi di, kakek mulai memberikan wejangan, "sebagai orang Minang kalian wajib memahami sumpah sakti nenek moyang kita di Bukit Marapalam dahulu kala. Begini bunyinya : 'adat bersendi syarak, syarak bersendi kitabullah, syarak mengata, adat memakai.' Maknanya, adat Minangkabau itu merujuk pada Al-Qur'an, agama yang memberikan fatwa, adat yang melaksanakannya. Antara agama dan adat itu tidak untuk dipertentangkan, tapi saling bersandar satu sama lain. Kalian amalkan agama, tapi kalian hormati pula adat istiadat yang kaya ini. Adat yang baik kita pakai, yang buruk kita buang." (Fuadi, 2018:163)

Dalam data [11] terjadi relasi kuasa antara tokoh kakek dengan Hepi cucunya. tokoh Kakek memberikan nasihat kepada cucunya bahwa antara adat dan agama itu saling berhubungan, saling terikat dan tidak bisa dipisahkan. Nasihat itu diberikan kepada cucunya untuk menanamkan pola pikiran yang positif, sehingga pikiran anak muda bisa terkontrol dengan baik.

\section{SIMPULAN}

Berdasarkan hasil penelitian dan pembahasan yang telah dilakukan maka dapat diambil simpulan sebagai berikut relasi kuasa dalam novel Anak Rantau karya Ahmad Fuadi berbentuk relasi kuasa atas pemikiran. Relasi kuasa atas pikiran dalam novel Anak Rantau karya Ahmad Fuadi berupa :

\section{Manipulasi :}

Para orangtua memanipulasi pemikiran anak-anak agar patuh kepada mereka. Adanya informasi itu akibat cerita yang disebarkan dari mulut ke mulut. Dan sering 
terjadi bahwa wacana tersebut dilebih-lebihkan dan jauh dari kenyataan yang ada. Relasi kuasa terjadi antara orangtua dan anakanak.

Stigmatisasi :

Terjadi relasi kuasa antara guru dengan orangtua ketika penerimaan raport. Dalam cerita tersebut dijelaskan bahwa guru berkuasa atas perilaku anak disekolah, sehingga guru mempunyai peraturan tentang kedisiplinan di sekolah, apabila mereka sudah memberi peraturan kemudian dilanggar, maka guru akan memberitahukan konsekuensinya kepada orang tua murid tersebut.

Dominasi :

$\begin{array}{lrr}\text { Masyarakat } & \text { pada } & \text { umumnya } \\ \text { berpikir } & \text { bahwa } & \text { dengan } \\ \text { mempunyai banyak uang dapat } & \text { dapalan } \\ \text { melakukan apa saja yang }\end{array}$
diinginkannya. Asupan itu dimasukkan terus menerus sehingga pikiran manusia terpengaruhi oleh kekuasaan materi duniawi.

Pengontrolan :

Terjadi relasi kuasa antara tokoh kakek dengan Hepi cucunya. tokoh Kakek memberikan nasihat kepada cucunya bahwa antara adat dan agama itu saling berhubungan, saling terikat dan tidak bisa dipisahkan. Nasihat itu diberikan kepada cucunya untuk menanamkan pola pikiran yang positif, sehingga pikiran anak muda bisa terkontrol dengan baik.

\section{DAFTAR PUSTAKA}

Damono, Sapardi Djoko. (2005). Sosiologi Sebuah Pengantar. Jakarta : Depdikbud.

Endraswara, Suwardi. (2011). Metodologi Penelitian Sastra Yogyakarta: Pustaka Pelajar.

Faruk. 2012. Pengantar Sosiologi Sastra. Yigyakarta: Pustaka Pelajar

Foucault, Michael. (2007). Arkeologi Ilmu-Ilmu Kemanusiaan. Yogyakarta: Pustaka Pelajar.

Fuadi, Ahmad.(2018). Anak Rantau. Jakarta : Falcon

Jones, Pip. (2012). Pengantar TeoriTeori Sosial. Jakarta: Yayasan Pustaka Obor Indonesia.

Pradopo, Rachmad Djoko. (2009). Metodologi Penelitian Sastra. Yogyakarta : Gadjahmada.

Siswantoro. (2010). Metode Penelitian Sastra. Surakarta : Pustaka Pelajar

Sulistya, Prima dkk. (2011). Karnaval Caci Maki. Yogyakarta : 
Ekspresi Buku

Swingewood. (2013). The Sociology

Sugiharto. (2012). Teknik Sampling.

Of Literature. New. York:

Jakarta : Gramedia Pustaka

Schocken Books

Utama. 